\title{
General Transcription Factor IIE Subunit 1
}

National Cancer Institute

\section{Source}

National Cancer Institute. General Transcription Factor IIE Subunit 1. NCI Thesaurus. Code C29677.

General transcription factor IIE subunit 1 (439 aa, 50 kDa) is encoded by the human GT F2E1 gene. This protein plays a role in both transcriptional initiation and RNA elongation. 